\title{
Relationship of Leadership Style to Completeness of Filling in The Early Nursing Assessment in Hospital
}

\author{
Prestasianita Putri ${ }^{*}$, Alfid Tri Afandi², Dian Wahyu Fajaryanti ${ }^{3}$ \\ ${ }^{1 *}$ STIKes dr.Soebandi, Jember, Indonesia; prestasianita@stikesdrsoebandi.ac.id (Corresponding Author) \\ 2Faculty of Nursing, Universitas Jember, Indonesia \\ ${ }^{3}$ Nurse Practitioner, Indonesia
}

\begin{abstract}
Article Info:
Submitted:

01-06-2021

Revised:

02-06-2021

Accepted:

02-06-2021

DOI:

https://doi.org/10.53713/nhs.v1i1.19

ABSTRACT

An initial assessment has a significant role in determining the correct nursing diagnosis, planning nursing actions, implementing actions, and assessing/evaluating nursing. Initial assessment data is incomplete, precise, and accurate resulting in nursing care not achieving optimal goals. This study aims to determine the relationship between leadership style and the completeness of filling out the initial inpatient nursing assessment at Bina Sehat Hospital Jember. The research design is a descriptive correlation with cross-sectional, data analysis chi-square, the total population of all inpatient nurses, with a complete sample of 79 nurses (total sampling). The results showed no relationship between leadership style and the completeness of filling out the initial inpatient nursing assessment at Bina Sehat Hospital Jember $(p=0.772)$. The majority of leadership style assessments are participatory (82.3\%), where from 79 nurse respondents, 47 nurses are prevalent with a working period of $>5$ years $(59.5 \%)$, while in terms of education, the majority of D3 nursing graduates are 40 nurses $(50.6 \%)$. Hospital agencies can maintain a participatory leadership style carried out by the head of the inpatient room to work together in decision-making that can increase nurses' creativity and work responsibilities. One of which is the completeness of nursing documentation so that it will create quality nursing services.
\end{abstract}

This work is licensed under CC BY-SA License.

Keywords: leadership style, head of the room, initial nursing assessment

\section{INTRODUCTION}

Law No.44 (2009) concerning Hospitals requires hospitals to carry out accreditation. The 2012 version of the Hospital Accreditation Commission (KARS) appointed by the Minister of Health has a standard that must complete the initial nursing assessment within 24 hours after the patient is admitted to hospital or sooner depending on the patient's condition or according to hospital policy. Completeness of filling out medical records 24 hours after completing service with a standard/target of $100 \%$. The quality of the fullness of the initial nursing assessment documentation is one indicator of the quality of the nurse's work (National indicators of hospital quality, SNARS Edition 1.1). The results of research related to the completeness of filling out nursing documentation carried out at the Brazilian General University Hospital were obtained from 112 records for the period before accreditation was $33 \%$. After accreditation was $19.6 \%$ (Nomura et al., 2016), research conducted in Cardiovascular and brain Center for RSUP Prof. DR RD Kandou, Manado showed that 10 out of 100 documentation files for the initial assessment of nursing care were incomplete (Edison et al., 2015). Data at Sanglah Hospital Denpasar obtained $40 \%$ of the initial nursing assessment data not by the standards/targets. Research conducted at the Kediri Baptis Hospital received as many as $48.3 \%$ (Triyoga, \& Prita, 2015).

Documentation is an authentic record in the application of professional nursing care management. Professional nurses are expected to face the demands of responsibility and accountability for all the actions they take, along with the increasing public awareness of the law so that complete documentation is needed (Nursalam, 2012). An initial assessment plays an essential role in determining appropriate nursing diagnoses, planning nursing actions, implementing actions, and nursing assessments. The initial assessment data is incomplete, precise, and accurate resulting in nursing care not achieving optimal goals. Patient problems are not resolved adequately (Zaidin, 2016), reducing the quality of nursing care performed (Ikhwanul, 2016). Factors that affect the completeness of the initial nursing assessment documentation include lack of knowledge and understanding of nurses. Nurses prioritize direct 
action and lack of personnel (Edison, 2015); education, training, facilities, policies, motivation, usefulness, organization, and leadership (Sumarsih, 2012).

The presence of the head of the nursing room will determine the success of his staff in carrying out effective and efficient work (Handayaningsih, 2009). Therefore, how the head of the room leads its members is very much needed. In this case, is what leadership style is used. According to Chapman, quoted by Dale Timpe in Umar (2000), five solid foundations of leadership include how to communicate, provide motivation, leadership skills, decision making, and positive power. The leadership style based on authority and power is divided into 4 (Gilles, 1996 in Nursalam, 2014), namely Authoritarian, Democratic, Participative, and Free of Action. The results of research from Caroline (2007) stated that participatory leadership style is positively related to the work integrity of its members. The participatory leadership style will also increase members' motivation in carrying out their duties, one of which is related to nursing care documentation (Ponto, 2011).

Based on Mariza's research (2016) at the Padang Panjang Hospital, adopting the initial assessment format from several nursing assessment books and the initial assessment format applied at M. Jamil Padang Hospital, the initial assessment format will be more effectively used in inpatient rooms by using the checklist method. The contents already include all items determined by KARS. The initial stage of the nursing process begins with completing the initial nursing assessment documentation so that it will make it easier to complete the following nursing process. Based on this, we are interested in researching the relationship between leadership style and completing the initial nursing assessment in a hospital inpatient room.

\section{METHOD}

The method used in this study is a descriptive correlation study with a cross-sectional approach. This design is done to find the relationship between variables to know the relationship between variables. The population in this study were nurses in a hospital with a total of 79 nurses. The sampling technique used is total sampling so that all the population of nurses is employed as respondents. In addition, the files used are 79 medical record files. The data collection technique used is by using a questionnaire.

\section{RESULT}

The results in this study were divided among other characteristic data of respondents, the data style of leadership and the data completeness assessment beginning to be served into some of the following table.

Table 1. Characteristics of Respondents ( $n=79)$

\begin{tabular}{|c|c|c|}
\hline Data Characteristics of Respondents & Total $(\mathrm{n})$ & Percent (\%) \\
\hline \multicolumn{3}{|l|}{ Type Gender } \\
\hline Male & 38 & 48.1 \\
\hline Female & 41 & 51.9 \\
\hline \multicolumn{3}{|l|}{ Age } \\
\hline$<25$ Years & 3 & 3.8 \\
\hline $25-35$ Years & 75 & 94.9 \\
\hline $36-45$ Years & 1 & 1.3 \\
\hline$>45$ Years & 0 & 0 \\
\hline \multicolumn{3}{|l|}{ Education } \\
\hline D3 Nursing & 40 & 50.6 \\
\hline S1 Nursing + Nurse & 39 & 49.4 \\
\hline \multicolumn{3}{|l|}{ Length of Work } \\
\hline$<1$ Year & 8 & 10.1 \\
\hline $1-5$ Years & 24 & 30.4 \\
\hline$>5$ Years & 47 & 59.5 \\
\hline
\end{tabular}

From table 1, it is found that the gender of the respondents is almost the same between men and women, while the majority of respondents are in the age range of 25-35 years. In nursing education, the vocational and nursing professions are almost the same, and the majority of them have worked for more than 5 years. 
Table 2. The style of leadership in the inpatient hospital

\begin{tabular}{|c|c|c|}
\hline Leadership style & Frequency & Percentage $(\%)$ \\
\hline Unfollow & 0 & 0.0 \\
\hline Authoritarian & 0 & 0.0 \\
\hline Participatory & 65 & 82.3 \\
\hline Democratic & 14 & 17.7 \\
\hline Total & 79 & 100,0 \\
\hline
\end{tabular}

From table 2 showed that the force the leadership style that is quite often used is the participatory leadership style.

Table 3. Distribution of the completeness of filling in the initial nursing assessment

\begin{tabular}{lccc} 
& Information & Frequency & Percentage (\%) \\
\hline Complete & & 38 & 48.1 \\
\hline Incomplete & & 41 & 51.9 \\
\hline & Total & 79 & 100.0 \\
\hline
\end{tabular}

From table 3, the results for complete and incomplete documentation are almost the same.

Table 4. Cross tabulation of leadership style with the completeness of the initial assessment of nursing

\begin{tabular}{rcccc}
\hline Description & & Full & Incomplete & Total \\
\hline \multirow{3}{*}{ Leadership Style } & Participatory & 32 & 33 & \\
\cline { 2 - 5 } & $65 \%$ & 49.2 & 50.8 & 100.0 \\
\cline { 2 - 5 } & Democratic & 6 & 8 & \\
\cline { 2 - 5 } & $14 \%$ & 42.9 & 57.1 & 100.0 \\
\hline
\end{tabular}

Statistical test results by using the fisher's test, the exact sig (2-sided) value obtained $p$ value $=0.772$ which indicates greater than the value $=0.05$, so from this value it can be said that there is no relationship between leadership style and the completeness of filling out the initial nursing assessment.

\section{DISCUSSION}

Following the results of research from Caroline (2007), it is stated that participatory leadership style is positively related to the work integrity of its members. The participatory leadership style will also increase members' motivation in carrying out their duties (Ponto, 2011). In carrying out leadership activities, a leader is influenced by several factors. Factors that influence leadership style include personality, expectations, and behavior of superiors, characteristics, task needs, climate, organizational policies, expectations, and colleagues' behavior (H Reitz 1981, quoted by Fattah 2010).

The participative leadership style involves the executive in decision-making and assigns responsibility for the task to the implementing nurse. The participatory and democratic leadership style positively influences nurses in decisionmaking, ideas, and ideas that can increase work commitment and productivity. The participatory and democratic leadership reflects an open attitude, can provide views and opinions, and has good performance to work together to be involved in decision-making that can increase nurses' creativity and work responsibility to create quality nursing services. Therefore, hospital agencies can maintain a participatory and democratic leadership style carried out by the head of the inpatient ward.

The analysis of the completeness of filling out the initial nursing assessment in the inpatient room from 79 medical record files obtained fill 38 medical record files (48.1\%), and 41 medical record files (51.9\%) were incomplete. These data are related to the results of research on the completeness of filling out nursing documentation carried out in several places, namely: at the Brazilian General University Hospital, it was obtained from 112 records for the period before accreditation was 33\% and the period after accreditation was 19.6\% (Nomura et al., 2016 ), research conducted at the Cardiovascular and Brain Center of Prof. DR RD Kandou Manado, showed that 10 out of 100 documentation files for the initial assessment of nursing care were incomplete (Edison et al., 2015). Data at Sanglah Hospital Denpasar 
obtained $40 \%$ of the initial nursing assessment data not by the standard/target. Research conducted at the Kediri Babtis Hospital received 48.3\% (Triyoga, \& Prita, 2015). An initial assessment plays an essential role in determining appropriate nursing diagnoses, planning nursing actions, implementing actions, and nursing assessments. The initial assessment data is incomplete, precise, and accurate resulting in nursing care not achieving optimal goals. Patient problems are not resolved adequately (Zaidin, 2016), reducing the quality of nursing care performed (Ikhwanul, 2016). Documentation is an authentic record in the application of professional nursing care management. Professional nurses are expected to face the demands of responsibility and accountability for all the actions they take, along with the increasing public awareness of the law so that complete documentation is needed (Nursalam, 2012).

Based on the results of the study, it was found that the Chi-square test with a significance value of fisher's exact test $p$-value of $0.772>0.05$. This shows no relationship between leadership style and the completeness of filling out the initial nursing assessment in the inpatient room. Factors that affect the totality of the initial nursing assessment documentation include lack of knowledge and understanding of nurses. Nurses prioritize direct action and lack of energy (Edison, 2015); education, tenure, training, facilities, policies, motivation, usefulness, organization, and leadership (Sumarsih, 2012). This is following the research conducted by Bella Wahyu Suyekti (2013) at Muhammadiyah Hospital Sruweng on 96 nurses and 337 medical record files. It found that $91.7 \%$ had D3 nursing education, $4.2 \%$ SPK, S1 nursing + nurses $1 \%$, S1 nursing $3.1 \%$. From the category of the length of service, $57.3 \%$ belongs to the category of new tenure, and $42.7 \%$ belongs to the category of the long service period-medical record files in wrong category $53.41 \%$ and good category $46.59 \%$. There is a relationship between the length of the nurse's tenure and the completeness of the inpatient medical record file with a significance $(p)=0.0001$ and a correlation coefficient $(r)=-0.216$. From the research of Proborini Putri Pratiwi at Tugurejo Hospital Semarang in 2013 using a cross-sectional approach with a sample of 85 nurses, data collected by SPSS chi-square test showed a significant relationship between education level and completeness of filling out nursing care assessment documentation with $p=0.02<0.05$.

The leadership style of the head of the room is an indispensable part of the performance of the implementing nurse. Still, it does not significantly affect the performance of the executor related to nursing care documentation. The connotation states that nurses with D3 nursing graduates are skilled nurses, and S1 nursing graduates + nurses are professional nurses. It is true. Changing habits that have been running for quite a long time is indeed not as easy as one might think. It requires unique strategies and tips to plan how, what kind of easy technique, and how often supervision is carried out to monitor it and how long it will take to evaluate it.

\section{CONCLUSION}

Based on the study results, it can be concluded that there is no relationship between leadership style and the completeness of filling out the initial nursing assessment in the hospital inpatient room. Leadership style can be a mechanism in leading and managing a nursing room, but filling in the completeness of the initial assessment depends on the nurse concerned in filling out the documentation.

\section{REFERENCES}

Afandi, A. (2016). Peer Group Support Effectivity Toward The Quality Of Life Among Pulmonary Tuberculosis And Chronic Disease Client : A Literature Review. Nurseline Journal, 1(2), 219-227. Retrieved From Https://Jurnal.Unej.Ac.Id/Index.Php/Nlj/Article/View/4901

Anggoro, M.T. (2007). Metodologi Penelitian. Jakarta : Universitas Terbuka.

Arrum, D. (2010). Hubungan Gaya Kepemimpinan Kepala Ruangan \& Karakteristik Perawat dengan Pemberdayaan Psikologis Perawat Pelaksana. Jakarta.

Arwani \& Supriyanto. (2006). Manajemen Bangsal Keperawatan. Jakarta: EGC.

Fattah, N. (2010). Landasan Manajemen Pendidikan. Bandung. PT Remaja Rosdakarya.

Handayaningsih. (2009). Dokumentasi keperawatan "DAR". Yogyakarta : Mitra Cendikia Press.

Hasibuan, M. S.P. (2016). Manajemen Sumber Daya Manusia. Edisi revisi.Jakarta : PT Bumi Aksara.

Irawan. (2015). Hubungan Gaya Kepemimpinan Kepala Ruang Dengan Pelaksanaan Praktik Caring Perawat Pelaksana.Jember: Universitas Negeri Jember.

Kartono \& Kartini. (2014). Pemimpin \& Kepemimpinan. Jakarta. PT Raja Grafindo Persada.

Nomura, Marcos \& Almeida. (2016). Quality of nursing documentation before and after the hospital accreditation in a university hospital. Brazil. http://pubmed.ncbi.nlm.nih.gov/27878216.com

Notoatmodjo, S. (2012). Metode Penelitian Kesehatan. Jakarta: Rineka Cipta.

Nursalam, (2014). Manajemen Keperawatan : Aplikasi dalam Keperawatan Praktek Profesional, Edisi 4, Jakarta : Salemba Medika

Olfah, Y. (2016). Dokumentasi Keperawatan. Jakarta. Kementrian Kesehatan Republik Indonesia.

Ponto, H. (2011). Pengaruh Kepemimpinan Partisipatif terhadap Motivasi Mengajar Guru SMK Negeri 2 Manado. Elematika, 1(1),15- 
20. Oktober 20, 2014.http://jurnalelektro.wordpress.com.

Potter, P. A. \& Perry, A.G. (2005). Buku Ajar Fundamental Keperawatan: Konsep, Proses, dan Praktik Ed. 4. Jakarta: EGC.

Rifai, A., Afandi, A., \& Hasanah, A. (2020). Bedside Nursing Handover: Patient's Perspective. NurseLine Journal, 4(2), 123-130. doi:10.19184/nlj.v4i2.15422

Setiadi. (2007). Konsep dan Penulisan Riset Keprawatan. Yogyakarta: Graha IImu.

Sugiyono. (2007). Metode Penelitian Kuantitatif Kualitatif dan R\&D. Bandung: Alfabeta.

Supriyatna. (2003). Manajemen Keperawatan \& Sumber Daya Apatur. Bandung. CV Indra Prahasta.

Triyoga \& Prita. (2015). Hubungan antara gaya kepemimpinan kepala ruang dengan kelengkapan dokumentasi pengkajian asuhan keperawatan. http://digilib.ukh.ac.id

Zaidin. (2009). Dasar-dasar Dokumentasi Keperawatan. Jakarta : EGC. 